ISSN 0258-7122 (Print), 2408-8293 (Online)

Bangladesh J. Agril. Res. 42(4): 693-705, December 2017

\title{
EFFECT OF BRACKISH WATER IRRIGATION ON SOIL DEGRADATION AND PERFORMANCE OF SALT TOLERANT WHEAT AND MAIZE GENOTYPES
}

\author{
M. R. FAROOQ ${ }^{1}$, J. AKHTAR ${ }^{2}$, M. I. SHAHID ${ }^{3}$ AND M. SAFDAR ${ }^{4}$
}

\begin{abstract}
A field experiment was conducted to study the effect of brackish water on soil physical and chemical conditions and yield of wheat and maize genotypes at the farmers' field. Two salt tolerant genotypes for each crop were selected from previous hydroponic and lysimeters studies. Wheat-maize cropping system was followed using tubewell brackish water alone and with chemical (gypsum) and organic (FYM) amendments. The results revealed that treatments have significant effect on all growth and yield parameters and followed the trend of $\mathrm{T}_{1}>\mathrm{T}_{3}>\mathrm{T}_{4}>\mathrm{T}_{2}$. Highest grain yield of wheat genotypes (SARC-1 \& V-8670) was observed in control $(4050 \& 3800 \mathrm{~kg} / \mathrm{ha})$ and lowest was in $\mathrm{T}_{2}(2862 \&$ $2200 \mathrm{~kg} / \mathrm{ha}$ ). Similar trend was observed in maize fodder yield that was $9625 \&$ $8875 \mathrm{~kg} / \mathrm{ha}$ in control and $4350 \& 2253 \mathrm{~kg} / \mathrm{ha}$ in $\mathrm{T}_{2}$ for Sahiwal-02 and Akbar, respectively. Maximum reduction in wheat grain and maize fodder yield observed in $\mathrm{T}_{2}$ (tubewell water alone) where high EC, SAR and RSC water was applied that was $39 \& 57 \%$ for $1^{\text {st }}$ year (wheat crop) and $89 \& 74 \%$ for $2^{\text {nd }}$ year (maize crop) respectively. Data revealed that use of gypsum and FYM along with brackish water improved the wheat grain yield and maize fodder as compared to $\mathrm{T}_{2}$. More adverse effect of brackish water was observed in high EC, SAR and RSC treatment (tubewell water alone) as compared to other treatments. Application of amendments (gypsum and FYM) along with brackish tubewell water reduced adverse effect of brackish water. Among genotypes SARC-1 and Sahiwal-2002 performed better in all treatments and textures especially under brackish water treatments.
\end{abstract}

Keywords: Brackish water, soil properties, genotypes, crop production.

\section{Introduction}

The rate of growing global population warrants increase in the area under irrigated agriculture to fulfill the future food and fiber needs, which will need additional amounts of water. Competition for freshwater already exists among the municipal, industrial and agricultural sectors in several regions due to an increase in population. This phenomenon is expected to continue and to intensify in less developed, arid region countries such as Pakistan, that already have high population growth rates and suffer from serious environmental problems (Qadir and Oster, 2004). As supplies of good-quality irrigation water are expected to decrease, available water supplies need to be used more efficiently, where one of

${ }^{1,3 \& 4}$ Chem. / Soil science Division, RARI Bahawalpur, ${ }^{2}$ ISES, University of Agriculture, Faisalabad. 
the techniques can be the reuse of saline and or sodic drainage waters (Oster, 2000). In Pakistan, to supplement the present canal water availability at farmgate (43 MAF), more than 531,000 tube wells are pumping 55 MAF water. Estimates show that about $70-80 \%$ of pumped water in Pakistan $\left(67,842\right.$ million $\left.\mathrm{m}^{3}\right)$ contains soluble salts and/or sodium ions $\left(\mathrm{Na}^{+}\right)$levels above the permissible limits for irrigation water (Latif and Beg,2004). The use of underground water for irrigation resulted in deterioration of soil physical and chemical properties (Sarwar et al., 2002).

There are two major approaches for improving and sustaining productivity in a saline environment: modifying the environment to suit the plant and modifying the plant to suit the environment. Both these approaches have been used, either singly or in combination, but the former has been used more extensively because it facilitates the use of alternative production inputs. Maize (Zea mays L.) is an important crop and provides raw material for agro-based industry. It is not only consumed by human beings in the form of food grains, but also provides feed for livestock and poultry. Maize is moderately salt tolerant crop; the threshold salinity for corn is $1.7 \mathrm{dSm}^{-1}$ (Maas and Grattan, 1999). Sufficient information is not available about the performance of different maize varieties and changes in chemical and physical properties of soil under our field conditions by irrigated with brackish tube well water. Wheat is the most important and largest cereal crop in Pakistan. It covers a large proportion of the total area under cultivation. Total wheat area of Pakistan is about 8.5 million hectares and the majority of wheat is grown in Punjab. In Pakistan the most efficient way to increase wheat yield is to improve the salt tolerance of wheat genotypes because increasing the salt tolerance of wheat is much less expensive for poor farmers in developing countries than using other management practices, e.g. leaching salt from the soil surface etc. (Qureshi and Barrett-Lennard, 1998). The main objective of this work was to developed a successful planning of brackish water use for wheat yield and maize fodder production, observed soil deterioration and select best genotypes which can be economically grown by irrigating with brackish tubewell water.

\section{Materials and Methods}

\subsection{Experimental site and seed source}

Field experiments were conducted to study the performance of wheat and maize genotypes under natural field condition. Wheat crop was sown during 2012 and maize fodder was sown during 2013 in same field and layouts' using available brackish water at farmers' field in T. T. Singh District. Wheat genotypes (SARC$1 \&$ V-8670) and maize (Sahiwal \& Akbar) were already tested in hydroponic and lysimeter studies in wire house at University of Agriculture, Faisalabad. Seed of wheat genotypes (8670 \& SARC-1) and maize genotypes (Sahiwal-2002 \& AKBAR) were collected from the Saline Agriculture Research Centre, Institute 
of Soil and Environmental Sciences and Plant Breeding and Genetic Department, University of Agriculture, Faisalabad and Fodder Research Institute, Sahiwal.

\subsection{Treatments}

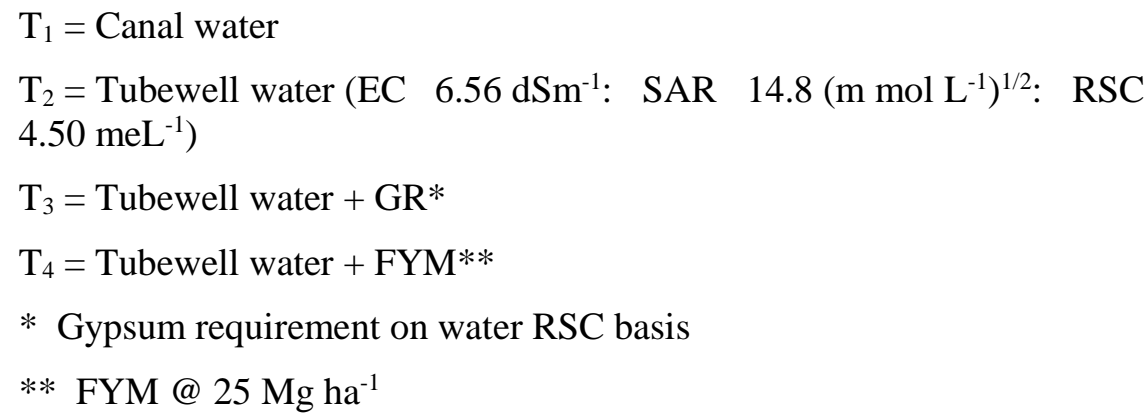

\subsection{Soil / Plant sample collection and analysis}

Initial soil sampling and analysis were done before start of experiments (Table 1). During the experiments soil sampling was done at pre-sowing and post harvesting of each crop. The soil samples were analyzed for chemical $\left(\mathrm{EC}_{\mathrm{e}}\right.$ \& SAR) and physical (Infiltration rate) characteristics. The fully expended leaf next to flag leaf at booting stage in wheat and at tesseling stage in maize were washed, cleaned, detached from plant and stored in separate eppendorf tubes at freezing temperature for leaf sap extraction to determine $\mathrm{Na}^{+}, \mathrm{K}^{+}$and $\mathrm{Cl}^{-}$. Determinations were done by using standard methods described by US Salinity Lab. Staff (1954).

Table 1. Initial physical and chemical characteristics of the soil $(0-30 \mathrm{~cm})$

\begin{tabular}{c|c|c|c}
\hline \multicolumn{4}{c}{ Physical analysis } \\
\hline Sand & Silt & Clay & Textural class \\
\hline 44 & 36 & 20 & Loam \\
Chemical analysis & & & Infiltration rate $\left(\mathrm{cm} \mathrm{h}^{-1}\right.$ \\
EC $_{\mathrm{e}}\left(\mathrm{dSm}^{-1}\right)$ & SAR $\left(\mathrm{mmol} \mathrm{L}^{-1}\right)^{1 / 2}$ & $\mathrm{pH}$ & 0.92 \\
3.15 & 3.39 & 7.72 & \\
\hline
\end{tabular}

\subsection{Experimental procedure}

In these experiments wheat-maize (fodder) cropping rotation was followed. Two genotypes for each crop were selected from solution culture and lysimeter experiments which are SARC-1 and V-8670 for wheat while Akbar and Sahiwal2002 for maize fodder. The tube well water contains EC $6.5 \mathrm{dSm}^{-1}$, SAR $10 \mathrm{(m}$ mol L $\left.{ }^{-1}\right)^{1 / 2}$ and RSC $4.50 \mathrm{meL}^{-1}$. The soil was prepared with ploughing and planking. Recommended dose of NPK was applied (120-90-60 $\mathrm{kg} \mathrm{ha}^{-1}$ ) for wheat and (200-150-200 kg ha-1) for maize in each lysimeter. Half of the $\mathrm{N}$ and all $\mathrm{P}$ 
and $\mathrm{K}$ were applied at the time of sowing while the remaining half $\mathrm{N}$ was added in two equal doses at tillering and booting stages in wheat and for maize fodder $2^{\text {nd }}$ dose of $\mathrm{N}$ was applied after 30 days of germination. Farm Yard Manure (FYM @ $25 \mathrm{Mg} \mathrm{ha}^{-1}$ ) and gypsum was applied according to gypsum requirement of water (Eaton, 1950) at sowing time. The five irrigations (2 inch) of brackish water were applied.

\section{Results and Discussion}

The study was carried out to determine the possibility of drainage water for crop production. Impact of different brackish water treatments with and without amendments on ECe, SAR, infiltration rate, Na:K ratio in leaf sap and crop yield and is discussed as under.

\subsection{Soil salinity $\left(\mathrm{EC}_{\mathrm{e}} \mathrm{dSm}^{-1}\right)$}

Soil analysis at different stages indicated that application of four types irrigation water has affected the soil salinity. The data regarding to change in ECe due to application of brackish water with and without amendments is shown in (Table 2). Maximum increase of $199 \%$ of basic salinity level was observed in $\mathrm{T}_{2}$ in which brackish water was applied without any amendments. However, same brackish tubewell water with gypsum (on RSC basis) minimized the adverse effect and reduced salinity build up ( $94 \%$ of basic salinity level) as compared to brackish water application. Similarly application of FYM also reduced salinity development (137\%).

Table 2. Impact of irrigation treatments on $\mathrm{EC}_{\mathrm{e}}$ of soil

\begin{tabular}{l|c|c|c|c}
\hline \multirow{2}{*}{\multicolumn{1}{c}{ Irrigation Treatments }} & \multicolumn{3}{c|}{$\mathrm{EC}_{\mathrm{e}}\left(\mathrm{dSm}^{-1}\right)$} & $\begin{array}{c}\text { Increase or } \\
\text { decrease in } \mathrm{S}_{3} \text { over } \\
\mathrm{S}_{1(\%)}\end{array}$ \\
\cline { 2 - 5 } & $\mathrm{S}_{1}$ & $\mathrm{~S}_{2}$ & $\mathrm{~S}_{3}$ & -14 \\
Canal water & 3.15 & 3.05 & 2.71 & +199 \\
Tubewell water & 3.15 & 7.34 & 9.43 & +94 \\
Tubewell water+GR* & 3.15 & 5.28 & 6.10 & +137 \\
Tubewell water+FYM** & 3.15 & 6.25 & 7.48 & \\
\hline
\end{tabular}

$\mathrm{S}_{1}=$ Soil analysis before sowing wheat

$\mathrm{S}_{2}=$ Soil analysis after harvesting wheat

$\mathrm{S}_{3}=$ Soil analysis after harvesting maize

* Gypsum requirement on water RSC basis

**FYM @ $25 \mathrm{Mg} \mathrm{ha}^{-1}$

Soil salinity increased due to accumulation of salts with brackish water application. It was reported that salt build up in soil increased with irrigation water salinity and mean increase in $\mathrm{EC}_{\mathrm{e}}$ of soil was $13.9\left(\mathrm{dSm}^{-1}\right)$ in $1^{\text {st }}$ year. Similarly, Sail et al. (2005) observed increase in $\mathrm{EC}_{\mathrm{e}}$ from 1.5 to $4.60\left(\mathrm{dSm}^{-1}\right)$ 
with waste water application. Soil salinity almost static with a slight decrease of $14 \%$ over the basic salinity level in the case of canal water irrigation. The effect of different treatments on ECe is described in Fig. 1 indicated that ill effect on brackish water can be minimized with use of gypsum (on RSC basis) and to some extant with application of FYM @ $25 \mathrm{Mg} \mathrm{ha}^{-1}$. Application of EC-SAR-RSC water along with gypsum and FYM minimized the adverse effect of brackish water and lowered the salt accumulation by improving soil aggregation and downward movement of water. Chaudhary et al., (2003) observed that gypsum application is required for maintaining yield of the crops irrigated with alkali water $\left(\mathrm{RSC}>10 \mathrm{me} \mathrm{L}^{-1}\right)$.

Fig. 1. Impact of irrigation treatments on final $\mathrm{EC}_{\mathrm{e}}$ of soil.

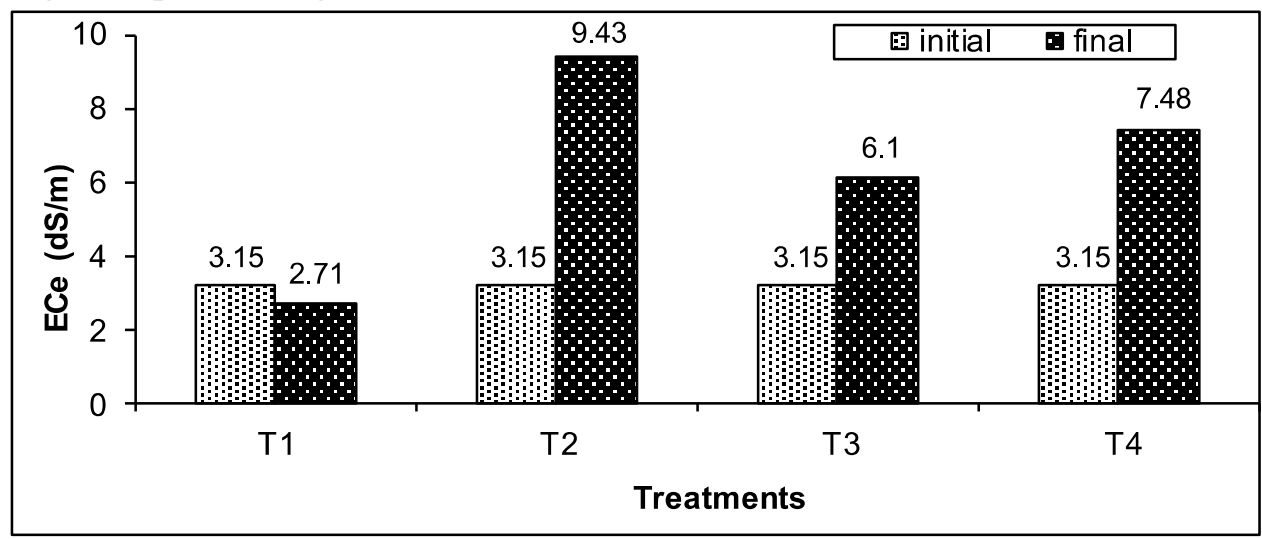

\subsection{Soil Sodicity (SAR)}

The data regarding SAR of soil as affected by application of brackish tubewell water alone and with amendments is presented in Table 3.

Table 3. Impact of irrigation treatments on SAR of soil

\begin{tabular}{l|c|c|c|c}
\hline \multirow{2}{*}{ Irrigation Treatments } & \multicolumn{3}{|c|}{$\mathrm{SAR}\left(\mathrm{mmol} \mathrm{L}^{-1}\right)^{1 / 2}$} & $\begin{array}{c}\text { Increase or } \\
\text { decrease in } \mathrm{S}_{3} \\
\text { over } \mathrm{S}_{1}(\%)\end{array}$ \\
\cline { 2 - 4 } & $\mathrm{S}_{1}$ & $\mathrm{~S}_{2}$ & $\mathrm{~S}_{3}$ & +34 \\
Canal water & 3.39 & 4.00 & 4.55 & +168 \\
Tubewell water & 3.39 & 7.05 & 9.07 & +95 \\
Tubewell water+GR* & 3.39 & 5.58 & 6.63 & +115 \\
Tubewell water+FYM** & 3.39 & 6.48 & 7.30 & \\
\hline
\end{tabular}

$\mathrm{S}_{1}=$ Soil analysis before sowing wheat

$\mathrm{S}_{2}=$ Soil analysis after harvesting wheat

$\mathrm{S}_{3}=$ Soil analysis after harvesting maize

* Gypsum requirement on water RSC basis

**FYM @ $25 \mathrm{Mg} \mathrm{ha}^{-1}$ 
Results indicated that application of canal water caused minimum increase in SAR (34\% over baseline salinity). However irrigation with brackish water $\left(\mathrm{T}_{2}\right)$ caused maximum soil salinity (168\%). Increase in soil SAR with brackish water was due to deterioration of soil structure, low infiltration rate and deficiency of nutrients. It is evident from previous observations that increase in soil SAR is directly proportional to $\mathrm{SAR}_{\text {iw }}$ under average management conditions. Increase in soil salinity in $\mathrm{T} 3$ and $\mathrm{Y} 4$ was $95 \%$ and $115 \%$, respectively. This reduction in SAR was due to use of gypsum (RSC basis) and FYM that eliminated the adverse effect of brackish water. It is easily deduced that gypsum application has helped reducing the soil SAR. The impact of brackish water treatments on soil sodicity is fairly visible in Fig. 2. Our results correlated with Murtaza et al. (2006). They observed significant increase in $\mathrm{EC}_{\mathrm{e}}$ and $\mathrm{SAR}$ with the application of saline sodic water in sandy clay loam soil. Use of amendments like gypsum is recommended especially when RSC $>5 \mathrm{me} / \mathrm{L}$, soils are medium textured and annual rainfall of the area is less than $500 \mathrm{~mm}$ (Minhas et al., 2004). Previously it was also reported that use of higher EC and SAR water increased soil EC ranged from 12$100 \%$ within three years along with increase in SAR of soil, but when this water is used with $100 \%$ gypsum applied to soil on RSC based of water, it decreased soil SAR (Chaudhary et al., 2003)

Fig. 2. Impact of irrigation treatments on final SAR of soil

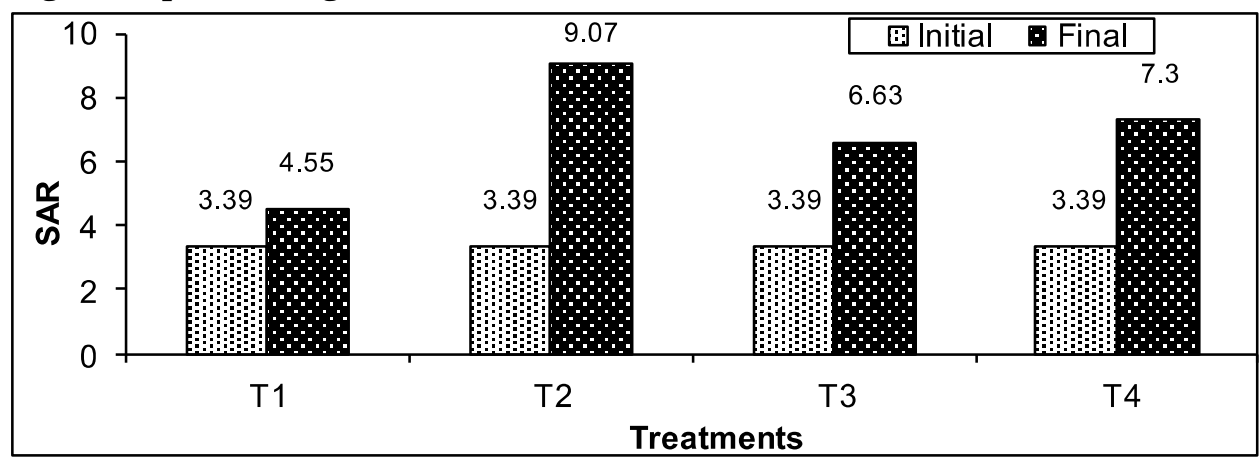

\subsection{Infiltration Rate (IR)}

Infiltration rate of soil was monitored before sowing and after harvesting of each crop to evaluate the changes due to application of brackish water application with and without amendments. Canal water application showed some improvement in the soil permeability and it was increased $(9 \%)$ over initial level at the end of experimental period. Application of brackish tubewell water continuously decreased infiltration rate and it was $26 \%$ less than initial rate at the end of experiment. Application of brackish water caused clay dispersion, which decreased infiltration rate and hydraulic conductivity. Swelling and dispersion increased with increasing $\mathrm{SAR}_{\mathrm{iw}}$ and $\mathrm{EC}_{\mathrm{iw}}$ that affected in lowering infiltration rate of water. Quirk (2001) confirmed higher HC (hydraulic conductivity) in low $\mathrm{Na}: \mathrm{Ca}$ ratio, and lower hydraulic conductivity in higher $\mathrm{Na}$ :Ca ratio in irrigation 
water. The application of irrigation water having different $\mathrm{Mg}: \mathrm{Ca}$ ratios $(2,4,8$ and 16), SAR (10, 25 and 50) and EC (2.0 and $\left.8.0 \mathrm{dS} \mathrm{m}^{-1}\right)$ increased the dispersion from 6.7 to $8.1,5.8$ to $7.25,3.0$ to $5.6,3.5$ to 4.6 , respectively that has caused surface sealing of soil pores and resulted in decreasing soil hydraulic conductivity, whereas hydraulic conductivity decreased from 6.5 to $5.5,1.55$ to $1.40,14.3$ to 13.1 and 34.0 to $32.0 \mathrm{~mm} \mathrm{~h}^{-1}$, respectively. Similarly decrease in infiltration rate and increase in bulk density also reported by Murtaza et al. (2002) when they used higher SAR (16.43) and RSC (5.57me L-1) water.

Table 4. Impact of irrigation treatments on infiltration rate of soil

\begin{tabular}{l|c|c|c|c}
\hline \multirow{2}{*}{ Irrigation Treatments } & \multicolumn{3}{|c|}{ Infiltration rate $\left(\mathrm{cm} \mathrm{hr}^{-1}\right)$} & Increase or decrease \\
\cline { 2 - 4 } & $\mathrm{S}_{1}$ & $\mathrm{~S}_{2}$ & $\mathrm{~S}_{3}$ & of $\mathrm{S}_{3}$ over $\mathrm{S}_{1}(\%)$ \\
\hline Canal water & 0.92 & 0.98 & 1.00 & +9 \\
Tubewell water & 0.92 & 0.73 & 0.68 & -26 \\
Tubewell water+GR* & 0.92 & 0.92 & 0.98 & +7 \\
Tubewell water+FYM** & 0.92 & 0.95 & 0.96 & +4 \\
\hline
\end{tabular}

$\mathrm{S}_{1}=$ Soil analysis before sowing wheat

$\mathrm{S}_{2}=$ Soil analysis after harvesting wheat

$\mathrm{S}_{3}=$ Soil analysis after harvesting maize

* Gypsum requirement on water RSC basis

**FYM @ $25 \mathrm{Mg} \mathrm{ha}^{-1}$

Salts like calcium and magnesium, do not adversely affect infiltration rate because these tend the cluster to clay particles. Calcium and magnesium will generally keep soil flocculated because these compete for the same spaces with sodium to bind to clay particles. Increased amounts of calcium and magnesium can reduce the amount of sodium-induced dispersion. The main concerns related to the relationship between salinity and sodicity of irrigation water are the effects on soil infiltration rate. It was also reported that the application of higher SAR water affect the infiltration rate besides giving rise to specific ion effect and nutrition imbalance in soil plant ecosystem (Azhar et al., 2003). In this study, infiltration rate was observed with brackish water application. The data regarding infiltration rate as effected by brackish water application with and without amendments, for wheat and maize crop production are presented in Table 4. The results revealed that application of gypsum and FYM along with brackish tubewell water improved the infiltration rate by $34 \%$ and $30 \%$ respectively as compared to irrigation with brackish water alone.

\subsection{Sodium Potassium Ratio in Cell Sap}

In present study brackish water treatments had significant impact on $\mathrm{Na}^{+}$and $\mathrm{K}^{+}: \mathrm{Na}^{+}$ratio. The maximum concentration of $\mathrm{Na}^{+}$was found in leaf sap of wheat and maize genotypes in the brackish tubewell water treatments that were $176.9 \&$ 
$210.9 \mathrm{~mol} \mathrm{~m}^{-3}$ in leaf sap of SARC-1 and V-8670, respectively. Similarly concentration of $186.5 \& 210.5 \mathrm{~mol} \mathrm{~m}^{-3}$ was found in leaf sap of Sahiwal-02 and Akbar followed tubewell water with FYM and tubewell water with gypsum (Table 5 \& 6). The present results confirmed the earlier finding of Wang et al. (2005) that irrigation waters differing in salt concentration affected growth and salt ion $\left(\mathrm{Na}^{+}\right)$accumulation in leaf of soybean.

Table 5. Impact of brackish water application on ionic concentration in leaf sap of wheat genotypes

\begin{tabular}{|c|c|c|c|c|c|c|c|c|}
\hline \multirow{3}{*}{$\begin{array}{l}\text { Irrigation } \\
\text { Treatments }\end{array}$} & \multicolumn{4}{|c|}{ Ionic concentration } & \multicolumn{4}{|c|}{ Decrease over control } \\
\hline & \multicolumn{2}{|c|}{$\begin{array}{l}\mathrm{Na}^{+} \text {conc. } \\
\left(\mathrm{mol} \mathrm{m}^{-3}\right)\end{array}$} & \multicolumn{2}{|c|}{$\mathrm{K}^{+}: \mathrm{Na}^{+}$ratio } & \multicolumn{2}{|c|}{$\begin{array}{c}\mathrm{Na}^{+} \text {conc. } \\
(\% \text { age })\end{array}$} & \multicolumn{2}{|c|}{$\begin{array}{l}\mathrm{K}^{+}: \mathrm{Na}^{+} \text {ratio } \\
\quad(\% \text { age })\end{array}$} \\
\hline & SARC-1 & 8670 & SARC-1 & 8670 & SARC-1 & 8670 & SARC-1 & 8670 \\
\hline Canal water & 54.2 & 50.75 & 2.85 & 2.5 & & & & \\
\hline Tubewell water & 176.9 & 210.9 & 0.81 & 0.64 & 226 & 316 & -72 & -74 \\
\hline $\begin{array}{l}\text { Tubewell } \\
\text { water+GR* }\end{array}$ & 127.8 & 135.7 & 1.17 & 1.05 & 136 & 167 & -59 & -58 \\
\hline $\begin{array}{l}\text { Tubewell water } \\
+ \text { FYM** }\end{array}$ & 145.4 & 142.5 & 0.98 & 0.98 & 168 & 181 & -66 & -61 \\
\hline
\end{tabular}

Table 6. Impact of brackish water application on ionic concentration in leaf sap of maize genotypes

\begin{tabular}{|c|c|c|c|c|c|c|c|c|}
\hline \multirow{3}{*}{$\begin{array}{l}\text { Irrigation } \\
\text { Treatments }\end{array}$} & \multicolumn{4}{|c|}{ Ionic concentration } & \multicolumn{4}{|c|}{ Decrease over control } \\
\hline & \multicolumn{2}{|c|}{$\begin{array}{l}\mathrm{Na}^{+} \text {conc. } \\
\left(\mathrm{mol} \mathrm{m}^{-3}\right)\end{array}$} & \multicolumn{2}{|c|}{$\mathrm{K}^{+}: \mathrm{Na}^{+}$ratio } & \multicolumn{2}{|c|}{$\begin{array}{c}\mathrm{Na}^{+} \text {conc. } \\
(\%)\end{array}$} & \multicolumn{2}{|c|}{$\mathrm{K}^{+}: \mathrm{Na}^{+}$ratio $(\%)$} \\
\hline & $\begin{array}{c}\text { Sahiwal- } \\
02\end{array}$ & Akbar & $\begin{array}{c}\text { Sahiwal- } \\
02\end{array}$ & Akbar & $\begin{array}{c}\text { Sahiwal- } \\
02\end{array}$ & Akbar & $\begin{array}{c}\text { Sahiwal- } \\
02\end{array}$ & Akbar \\
\hline Canal water & 48.05 & 40.5 & 3.72 & 4.01 & & & & \\
\hline $\begin{array}{l}\text { Tubewell } \\
\text { water }\end{array}$ & 186.5 & 210.5 & 1.08 & 0.82 & 288 & 338 & -71 & -80 \\
\hline $\begin{array}{l}\text { Tubewell } \\
\text { water } \\
+ \text { GR* }\end{array}$ & 144.5 & 183.13 & 1.20 & 0.91 & 201 & 281 & -68 & -77 \\
\hline $\begin{array}{l}\text { Tubewell } \\
\text { water } \\
+ \text { FYM** }\end{array}$ & 150.25 & 180.13 & 1.22 & 0.9 & 213 & 275 & -67 & -78 \\
\hline
\end{tabular}

The results of this study show that $\mathrm{K}^{+}: \mathrm{Na}^{+}$ratio in leaf sap varies among the genotypes as well as treatments. Highest $\mathrm{K}^{+}: \mathrm{Na}^{+}$ratio was observed in cell sap of 
SARC-1 (wheat genotype) and Sahiwal-02 (maize genotype) as compared to other genotypes sown in same growth conditions. Lowest ratio was observed in wheat and maize genotypes with brackish water irrigation. However, use of gypsum and FYM along with brackish water minimized the adverse effect of high salt concentration in irrigation water. It has been suggested that tolerant species have ability to maintain higher $\mathrm{K}^{+}$and lower $\mathrm{Na}^{+}$uptake as compared to salt sensitive species, while the most sensitive variety contained a 4-fold greater $\mathrm{Na}^{+}$concentration in shoots than the most tolerant variety. Our results confirmed the finding of Azevedo Neto and Tabosa (2000) that $\mathrm{Na}^{+}$concentration increased in leaf of salt stressed maize plant. It was inferred that the genotypes possess high $\mathrm{K}^{+}: \mathrm{Na}^{+}$ratio can be used as selectivity characteristic of salt tolerance (Poustini and Siosemardeh, 2004). Therefore, SARC-1 and Sahiwal-02 maintained high $\mathrm{K}^{+}: \mathrm{Na}^{+}$ratio even at high salt concentration in irrigation water and it tolerated these adverse conditions.

\subsection{Crop Yield}

The plant height of randomly selected plants of wheat and maize genotypes were measured at maturity stage. However, wheat grain yield and maize fodder weight were evaluated on whole plot basis to avoid any variation in experimental area and explained as under:

\subsection{Wheat grain yield $(\mathrm{kg} / \mathrm{ha})$ and plant height $(\mathrm{cm})$}

The data regarding the grain yield and plant height of wheat genotypes are presented in Fig. 3 and 4 showing reduction in plant height and grain yield with brackish water application. Lowest plant height was observed in tubewell water application which was $62 \mathrm{~cm}$ and $49 \mathrm{~cm}$ as compared to canal water treatment which was $83 \mathrm{~cm}$ and $82 \mathrm{~cm}$ in SARC-1 and V-8670, respectively. Similar effect was observed on grain yield of wheat genotypes that was decreased $30 \%$ and $42 \%$ over canal water treatment in SARC-1 and V-8670, with application of brackish tubewell water. These findings are correlated with ealier studies of Hamdy et al. (2005) observed that saline water $\left(9 \mathrm{dSm}^{-1}\right)$ decreased wheat grain yield upto $25 \%$ when compared with canal water treatment. The variation in the behavior of wheat genotypes indicated that SARC-1 produced better yield as compared to V-8670 under all treatments. Overall results show that application of brackish water along with FYM was comparatively more effective than other brackish water treatments in overcoming the adverse effect of poor quality water due to addition of organic matter which improved the soil physical conditions and improved infiltration rate. Use of gypsum minimized the decrease effect of brackish water and improved soil conditions and crop yields (Chaudhary et al., 2004). 
Fig. 3. Impact of brackish water application on plant height of wheat genotypes
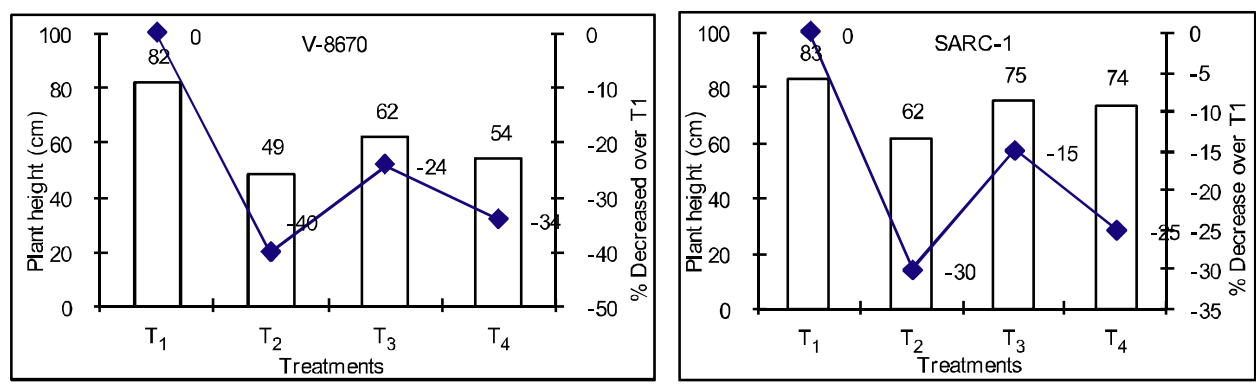

Fig. 4. Impact of brackish water application on grain yield of wheat genotypes
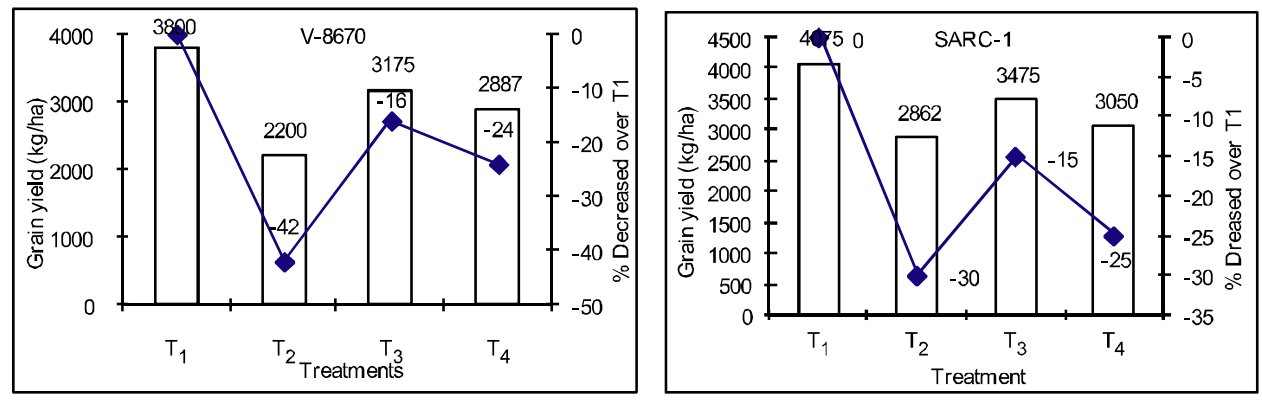

$\mathrm{T}_{1}=$ Canal water

$\mathrm{T}_{2}=$ Tubewell water

$\mathrm{T}_{3}=$ Tubewell water $+\mathrm{GR}$

$\mathrm{T}_{4}=$ Tubewell water $+\mathrm{FYM}$

\subsection{Maize fodder yield and plant height}

On an overall average basis, maize plant height and fodder yield reduced in brackish water treatments. The maximum plant height was recorded in Sahiwal02 genotype with canal water treatment $\left(315,195,260\right.$ and $245 \mathrm{~cm}$ in $T_{1}, T_{2}, T_{3}$ and $\mathrm{T}_{4}$, respectively) and similarly, maximum fresh biomass was also obtained from the same genotype $\left(96250 \mathrm{~kg} \mathrm{ha}^{-1}\right)$ with canal water application. Application of brackish tubewell water reduced growth parameters of both maize genotypes, the maximum reduction in plant height (49\%) and fresh biomass (75\%) being observed in Akbar as compared to Sahiwal-02. Relative yield decreased with increasing irrigation water salinity and time interval between irrigations (Feng and Cong, 2003) was also noticed.

Irrigation with brackish water reduces plant growth and biomass. As shown in Fig. $5 \& 6$, the reduction in plant height and fodder yield was maximum in brackish tubewell water application treatment as compared to control and other treatment. The reduction in fresh biomass was more with tubewell brackish water application due to more accumulation of salts which deteriorated the soil physical 
condition. The management practices to be followed for optimal crop production with brackish water must aim at preventing the build up of salinity, sodicity and toxic ions in the root zone to levels that limit the productivity of soils. Previously Chaudhary et al. (2003) also reported an improvement in crop yield in brackish water along with gypsum treatment as compared to brackish water irrigation.

Fig. 5. Impact of brackish water application on plant height of maize genotypes
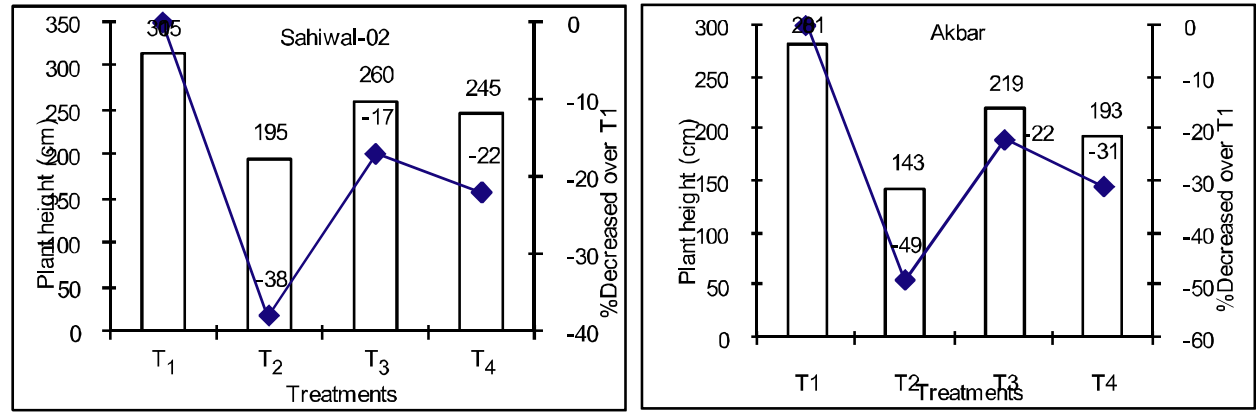

Fig. 6. Impact of brackish water application on biomass weight of maize genotypes
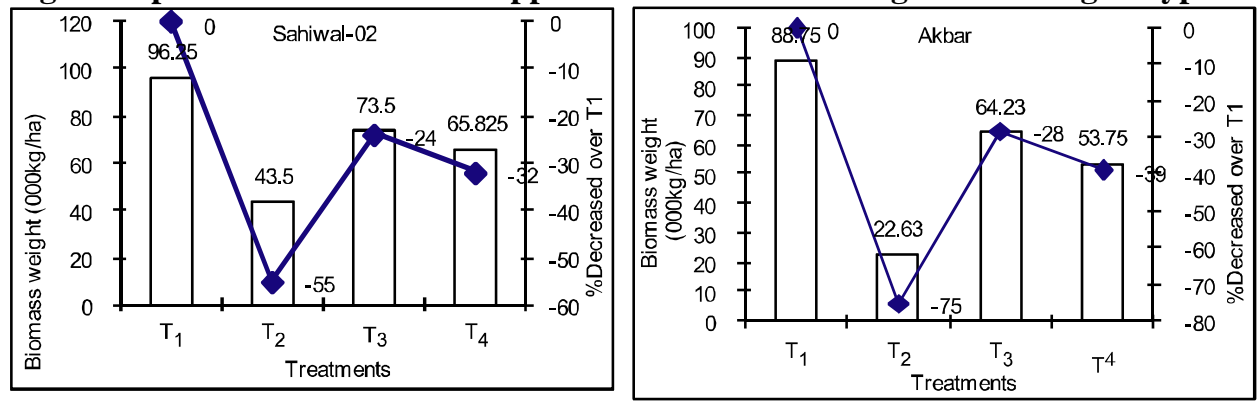

$\mathrm{T}_{1}=$ Canal water

$\mathrm{T}_{2}=$ Tubewell water

$\mathrm{T}_{3}=$ Tubewell water $+\mathrm{GR}$

$\mathrm{T}_{4}=$ Tubewell water $+\mathrm{FYM}$

\section{Conclusion}

1. Application of brackish tubewell water for crop production results in build up of soil salinity and cause reduction in yield.

2. Wheat and maize fodder yield are enhanced if brackish tubewell water is applied with gypsum requirement. It has been observed that FYM also have important role to minimize adverse effect of brackish tubewell water on crop production.

3. Wheat genotype SARC-1 and maize genotype Sahiwal-2002 performed better with application of brackish tubewell water alone or with amendments. 


\section{References}

Azhar M. J., M. T. Yamin and C. K. Ali. 2003. Ground water exploitation and application: the major issues. Paper prepared for $3^{\text {rd }}$ International civil Engineering Congress, 21 $1^{\text {st }}-22^{\text {nd }}$ Feb., 2003, Karachi Bajawa, M. S. and A. S. Josan. 1989b. Prediction of sustained sodic irrigation effects on soil sodium saturation and crop yield. Agric. Water Manage. 16: 217-228.

Azevedo Neto, A.D. and J.N. Tabosa. 2000. Salt stress in maize seedling: II. Distribution of cation macronutrients and its relation with sodium. Rev. Bras. Agric. Amb. 4: $165-171$.

Chaudhary, M. R., Iqbal, M., Subhani, K. M. 2003. Use of brackish drainage water effluent for crop production 9th International Drainage Workshop, September 10- 13, 2003, Utrecht (The Netherlands).

Eaton, R.P. 1950. Significance of carbonates in irrigation waters. Soil Sci., 69: 123-133.

Feng, Y.Y. and C.Z. Cong. 2003. Equilibrium of organic matter in heavy fraction for three long term experimental field soils in China. Pedosphere. 16(2):177-184.

Hamdy, A., V. Sardo , K.A. Farrag Ghanem. 2005. Saline water in supplemental irrigation of wheat and barley under rain fed agriculture. Agric. Water Manage. 78: 122-127.

Latif.M. and A. Beg. 2004. Hydrosalinity issues, challenges and options in OIC member states. In: M. Latif, S. Mahmood and M.M. Saeed, Editors, Proceedings of the International Training Workshop on Hydrosalinity Abatement and Advance Techniques for Sustainable Irrigated Agriculture, 20-25 September Lahore, Pakistan (2004), pp. 1-14.

Maas, E.V. and S. R. Grattan. 1999. Crop yield as affected by salinity. In. R.W. Skaggs and J. van Schilfgaarde, eds., agricultural Drainage. Agron. Monograph 38. ASA, CSSA, SSSA, Madison, WI.

Minhas, P.S., D.R. Sharma, C.P.S. Chauhan. 2004. Management of saline and alkali waters for irrigation. In: Advances in Sodic Land Reclamation, International conference on "Sustainable Management of Sodic management Pak. J. Agri. Sci. 35:16-23.

Murtaza, G., S.H. Shah, A. Ghafoor, S. Akhtar and N. Mahmood. 2002. Management of brackish water for crop production under arid and semi-arid conditions. Pak. J. Agric. Sci. 39:166-170.

Murtaza G., A. Ghafoorand M. Qadir. 2006. Irrigation and soil management strategies for using saline-sodic water in a cotton-wheat rotation. Agri. Water management, 81: $98-114$.

Oster, J.D. 2000. Irrigation sustainability. In: Proceedings of the Sixth International Micro-irrigation Congress, 22-27 October 2000. Cape Town. ICID-CIID. Plenary Session, P6. CD Rom. Document Transformation Technologies, POB 560, Lirene, 0062, South Africa.

Poustini, K. and A. Siosemardeh. 2004. Ion distribution in wheat cultivars in response to salinity stress. Field Crops Res. 85: 125-133. 
Qadir. M. and J.D. Oster, 2004.Crop and irrigation management strategies for salinesodic soils and water aimed at environmentally sustainable agriculture, Sci. Total Environ. 323: 1-19.

Quirk, J.P. 2001. The significance of the threshold to turbidity concentrations in relation to sodicity and microstructure. Aust. J. Soil Res. 39: 1185-1217.

Qureshi, R.H. and E.G. Barrett-Lennar. 1998. Three approaches for managing saline, sodic and waterlogged soils. P: 19-24 In: Saline Agriculture for irrigated land in Pakistan. A Hand book, ACIAR, Cambera, Australia.

Sail, J.K., S. Bibi and A.S.Qurashi. 2005. Environmental impact of sewage water irrigation on ground water quality. Pak. J. Water Res. 9: 49-53.

Sarwar, G., N. Hussain, J. Iqbal, M. Aslam and A. Hassan. 2002. Correlation of brackish water and physical properties of silty clay loam soil. Pak. J. Agric. Sci. 39: 250-257.

U. S. Salinity Laboratory Staff. 1954. Diagnosis and improvement of saline and alkali soils.USDA Handbook, vol. 60. US Government Printing Office, Washington, DC, USA.

Wang, D., C.M. Grieve and D.L Suarez. 2005. Composition of irrigation water salinity affects growth characteristics and uptake of selenium and salt ions by soybean. $J$. plant nutrition 28: 1073-1088. 
